\title{
Performance indicators for developer and homebuilder Mexican companies: A Delphi study
}

Indicadores de desempeño para empresas promotoras-constructoras mexicanas: Estudio Delphi

Kevin Luna Villarreal (Main Author)

Departamento de Ingeniería Civil, Instituto Tecnológico y de Estudios Superiores de Monterrey

Eugenio Garza Sada 2501, 64849 Monterrey, N.L., Mexico

kluna@itesm.mx

Eugenio Pellicer (Corresponding Author)

Escuela Técnica Superior de Ingenieros de Caminos, Canales y Puertos, Universitat Politécnica de València

Camino de Vera s/n, Valencia 46022 (Spain), Tel. +34963879562, Fax. +34963877569

pellicer@upv.es

Salvador García Rodriguez

Departamento de Ingeniería Civil, Instituto Tecnológico y de Estudios Superiores de Monterrey

sgr@itesm.mx

Manuscript Code: 726

Date of Acceptance/Reception: 31.03.2017/11.01.2016

DOI: $10.7764 /$ RDLC.16.1.133

\begin{abstract}
Performance measurement in residential housing, at a company or project level, is usually assessed using financial performance indicators. There are other performance indicators that can be also applied to the construction industry. The literature review identified papers and reports that propose a set of indicators that can be applied to different areas. However, there is no evidence of a system that comprises the key performance indicators at the design-bid-build-delivery stages of the life-cycle of developer and homebuilder companies. Therefore, the main goal of this research is to create a model of performance indicators (at the strategic, tactical and operative levels), based on the production chain of a developer and homebuilder company. Once the theoretical proposal is set, a Delphi study is developed so a panel of 11 experts assesses and summarize the indicators that allow measuring the performance of Mexican developer and homebuilder companies.
\end{abstract}

Key words: Performance, residential housing, indicator, Mexico, model.

Resumen

La medición del desempeño en la edificación residencial, tanto a nivel empresarial como de proyecto, se ha evaluado normalmente mediante indicadores de desempeño de tipo financiero. Existen otros indicadores de desempeño que también son aplicables al sector de la construcción. En la revisión de la literatura se identificaron diversos artículos e informes que proponen una serie de indicadores aplicables a diferentes áreas. Sin embargo, no hay evidencia de un sistema específico que integre los indicadores clave de desempeño en las etapas de diseño-contrataciónconstrucción-entrega del ciclo de vida de las empresas promotoras-constructoras de vivienda. Por lo tanto, el objetivo principal de esta investigación es cubrir esta laguna del conocimiento, generando un modelo de indicadores de desempeño (a nivel estratégico, táctico y operativo), basado en la cadena productiva de una empresa promotora-constructora de viviendas. Una vez realizada la propuesta de modelo teórico, se lleva a cabo un estudio Delphi con la finalidad de que un panel de 11 expertos valore y sintetice los indicadores que permitan medir el desempeño de las empresas promotoras constructoras de vivienda, en el contexto de la industria de la construcción mexicana.

Palabras clave: Desempeño, edificación residencial, indicador, México, modelo.

Introduction

The construction industry is characterized by its low productivity, fragmentation, division of responsibilities, and lack of alignment among the parties (O’Brien, Formoso, Vrijhoef \& London, 2009; Skibniewski \& Ghosh, 2009). Highly criticized for its poor performance and the lack of performance measurement systems (Kagioglou, Cooper \& Aouad, 2001), as well as the failure to achieve previously planned targets (Haponava \& Al-Jibouri, 2010). Some authors (O'Brien, Formoso, Ruben, et al., 2009) consider that the performance sector is poor; others are even calling it wasteful, inefficient and ineffective (Beatham, Anumba, Thorpe \& Hedges, 2004).

In the past two decades, many researchers emphasized the complexity of the processes used in the construction industry (Pellicer, Yepes, Teixeira, Moura \& Catala, 2014a; Winch, 2010). Compared with other sectors, researchers highlight the performance deficiencies of the construction processes and the evident need to improve their efficiency as described in "Constructing the Team" (Latham, 1994) and Eagan (1998) in their reports on the construction sector in the United Kingdom (UK). 
As a part of the management, performance measurement inherently exists dating back to the first information used in planning and control by the US Railroads in the late nineteenth century; subsequently, the highly competitive market environment, led to performance measuring which became a crucial factor to the success of a business (Bassioni, Price \& Hassan, 2005). In different countries, performance measurement systems were raised, developed and incorporated looking for an increased competitiveness (CII, 2011). However, most of the times, performance measurement has been limited to financial indicators based on measurements that are often criticized for being out of context (Kaplan \& Norton, 2003).

There are different proposals for specific indicators in the construction industry (Lim, Jung, \& Lee, 2015; Sarkar, Raghavendra \& Ruparelia, 2015; Kim \& Lee, 2015; Neyestani \& Juanzon, 2016), among others. Specifically, in Latin America several investigations were conducted to improve the performance using indicators linked to business strategy (Costa, Formoso \& Lantelme, 2002; Formoso \& Lantelme, 2000), or defined a system of "benchmarking" based on performance indicators (Costa, Formoso, Kagioglou, Alarcón \& Caldas, 2006; Ramirez, Alarcón \& Knights, 2004), none of them specifically related to the production cycle of housing; in addition, no research has been found that surveyed a particular or specific model to integrate strategy, performance measurement, and traceability objectives using key performance indicators in developer and homebuilder companies. This is the knowledge gap detected and, therefore, the starting point of this research.

The main objective of this research is to generate a theoretical model, validated by a panel of experts to identify which the strategic indicators are for evaluating the success of a construction project from the point of view of a developerbuilder in the residential market. To fulfill this objective the following steps have been taken: (1) identification of performance indicators in the literature; (2) selection of key indicators by a panel of experts; and ( 3 ) integration of these indicators into a model which allows their implementation within a company. To do this, first, the literature review is synthesized and, therefore, a relationship of indicators that make up a performance model is proposed. These indicators are summarized applying the Delphi method to a panel of 11 experts. Next, the model is described and commented. Finally, conclusions are drawn and limitations of the research are set.

\section{Performance measurement and key performance indicators}

During the sixties and seventies, performance measurement based on financial indicators generated some discontent, mainly due to the mismatch of information reporting at the end of the process and not when the process was ongoing. In addition, to make decisions in real time managers needed new, nonfinancial information (Bassioni et al., 2005). Nowadays businesses need to meet specific customer requirements, have flexible manufacturing processes, coordinate suppliers, and resources along the supply chain, and further optimize costs (Nudurupati, Bititci, Kumar \& Chan, 2011). As a result, companies require managers to keep abreast of information regarding organizational performance; they require predictive measures, indicating what will happen next week, month or year (Neely, Bourne, Mills, Platts \& Richards, 2002).

The need to develop performance measurement systems in the construction industry is even greater since production and management are done on a project basis (Hwang \& Zhao, 2015; Pellicer et al., 2014), making it necessary an additional resource control (Yu, Kim, Jung \& Chin, 2007). However, many construction companies still depend on performance measurement systems focused only on financial returns (Kagioglou et al., 2001). Some authors (Beatham et al., 2004) suggest the need for specific indicators for construction companies to address the particular characteristics of the production and management of projects.

In current businesses, performance measurement is the basis for performance evaluation of human resources, formulating the corporate strategy (Yu et al., 2007). In addition, measurements must be aligned according to the vision, mission, and strategies of the organization at all levels and aspects (Beatham et al., 2004). Strategy takes an important role to assess the level of performance and generate a "benchmarking" using KPIs; the results of the evaluation should be estimated periodically. In calculating the weight of each indicator their different priorities should be taken into account (Yu et al., 2007). In the development of the system, it is important to have security measures to protect information (Pellicer et al., 2014).

Construction is a difficult and complex task (Chan \& Chan, 2004). Modern managers need updated and mainly nonfinancial information for making and implementing optimal decisions (Bassioni et al., 2005). Rouse, Putterill \& Ryan (1997) indicate that overly simple performance measurements capture only a limited perspective of the company's activities. Meanwhile, Towill (2001) states that "it is important to emphasize that the improvement in performance metrics of a business (e.g. cost) must not be sought at the expense of another (quality and safety)". Each project can be 
seen as an orderly delivery process where all parties in the logistics chain are involved (Wegelius-Lehtonen, 2001). Therefore, performance measures are required to improve the logistic processes of the construction industry.

There are some well-defined metrics for measuring performance during the construction phase of the project; most of them are built around techniques such as critical path and earned value method (PMI, 2013). In the case of key performance indicators, the most commonly accepted are those that can physically be measured in monetary, time or other units (Cox, Issa \& Ahrens, 2003). However, it is found that performance metrics between the phases are not linked and can lead to a poor performance of the project (Pillai, Joshi \& Rao, 2002).

Performance measurement plays an important role in ensuring the success of a project and its subsequent usefulness for the company (Pillai et al., 2002). It is also considered an integral part of management and has been practiced since the administration exists (Bassioni et al., 2005). A project is considered successful if it meets the cost and time with the functional and technical requirements as well as customer expectations (Pellicer et al., 2014; Kärnä \& Junnonen, 2016). The concept of project success is developed through a series of criteria and standards by which project managers can fulfill them with the most favorable results. According to Cheung, Suen \& Cheung (2004), the success of a construction project depends on many factors such as complexity, contractual arrangements, and relationships among participants, the competence of project managers, and the skills of the key project members. A successful project delivery requires the concerted effort of the project team to perform various project activities, being the project manager responsible for completing the work.

With the foregoing information it is clear that an adequate performance measurement system should include: (a) an effective mechanism for evaluating objectives (Ghalayini \& Noble, 1996); (b ) a process for developing and evaluating indicators (Neely et al., 2002); (c ) a system for data comparison or "benchmarking" (Ramirez et al., 2004); and (d) adequate auditing tools (Bititci, Carrie \& McDevitt, 1997).

Several studies were implemented in the construction industry using performance measurement systems: for example, Alarcon \& Ashley (1996) propose performance measurement classified by cost, predicted value, and effectiveness. In the last two decades, the Construction Industry Institute (CII, 2011) has developed indicators and performance metrics for construction companies in the United States. In the United Kingdom, as a result of Latham (1994) and Eagan (1998) reports, DETR (2000) carried out a similar job. In Brazil, a research line focused on performance measurement was developed (Costa et al., 2002; Formoso \& Lantelme, 2000); from a total of 180 indicators of literature review and professional practice, 28 were selected to integrate a construction industry comparative database and implemented in construction companies. In Chile, a system of "benchmarking" for construction companies with 10 basic indicators (Ramirez et al., 2004) was generated. Finally, Costa et al. (2006) pointed out areas of opportunity and lessons learned from existing systems in both Latin America and the United Kingdom; according to these authors, the performance measurement systems and the "benchmarking" allow, regardless of the country where they are applied, permeating good practices and knowledge in the construction industry. There are other studies that focus on performance measurement at the company level (Bassioni et al., 2005; Beatham et al., 2004; Cheah, Garvin \& Miller, 2004) or at the project level (Yu et al., 2007)

According to Beatham et al. (2004), the following five problems are associated with the introduction of performance indicators in the construction sector:

1. It focuses on "Key Performance Outcomes" (KPOs or after the event measurements). There is an important need to understand the difference between "lagging" and "leading" measurements.

2. Key Performance Indicators (or KPIs) are not aligned with the business strategy. The literature shows that other sectors concluded that measures should be developed taking into account the objectives of the organization (Kaplan \& Norton, 1996).

3. Performance indicators were designed to make comparisons between companies, but due to the different strategies employed and the confidentiality of certain data, this is not possible. They have been used more as a marketing tool than for improvement.

4. KPIs are not providing a snapshot of all types of companies.

The KPIs are not incorporated into a performance measurement system that includes review and action. Two cycles are identified: (1) implementation of measures and (2) change of action depending on the results. Subsequent studies introduced new indicators (Neely et al., 2002) that expanded that excessively financial view of performance. The objective was to obtain an integrated, dynamic, and accessible system to facilitate rapid response to the company (Bititci et al., 1997). In the routine operation of the company as well as in general for the senior management responsible for strategic decision-making, performance measurement is critical; therefore, for a performance measurement system to 
function properly there must be a commitment of the management of the company, from the design phase to the implementation, use, and monitoring.

From the foregoing review through the literature, it can be determined that the goal of this research is to establish a model of specific performance indicators for developer-builders in the housing sector. Given this starting point, as well as some of the contributions mentioned above, in the next section, the performance indicators that are considered suitable for these developer-builders are formulated.

Table 1. Literature associated with performance indicators in the construction industry. Source: self-elaboration.

\begin{tabular}{|c|c|c|c|c|c|c|c|c|c|c|c|c|c|}
\hline (Ali, Al-Sulaihi \& Al-Gahtani, 2013) & & $*$ & $*$ & & $*$ & $*$ & $*$ & * & * & * & $*$ & $*$ & \\
\hline (Balatbat, Lin \& Carmichael, 2010) & & & & & & $*$ & & & & & & & \\
\hline (Bassioni et al., 2005) & $*$ & $*$ & $*$ & & & & & & * & & & $*$ & \\
\hline (Beatham et al., 2004) & & & & & & & & $*$ & & & & & \\
\hline (Butcher \& Sheehan, 2010) & $*$ & $*$ & $*$ & & & & $*$ & $*$ & * & * & & & \\
\hline (Chan \& Chan, 2004) & $*$ & $*$ & $*$ & & & $*$ & $*$ & $*$ & $*$ & & & & \\
\hline (Chan, 2009) & $*$ & $*$ & $*$ & & $*$ & $*$ & $*$ & & $*$ & * & & $*$ & \\
\hline (Cheah et al., 2004) & & & & & & $*$ & & & & & & & \\
\hline (Cheung et al., 2004) & $*$ & $*$ & $*$ & & & & $*$ & * & $*$ & & $*$ & & \\
\hline$(\mathrm{CII}, 2011)$ & $*$ & & & $*$ & $*$ & & $*$ & & & & $*$ & & \\
\hline (Constructing Excellence, 2011) & ${ }^{*}$ & $*$ & $*$ & & $*$ & & $*$ & * & $*$ & & & & \\
\hline (Cox et al., 2003) & $*$ & $*$ & $*$ & & $*$ & & $*$ & * & * & & & $*$ & \\
\hline (Dawood, 2010) & $*$ & $*$ & & & $*$ & & $*$ & $*$ & $*$ & & $*$ & $*$ & \\
\hline$(\mathrm{DETR}, 2000)$ & ${ }^{*}$ & $*$ & $*$ & $*$ & $*$ & & $*$ & & $*$ & & & & \\
\hline (Eagan, 1998) & $*$ & $*$ & $*$ & & $*$ & & $*$ & & $*$ & & & & \\
\hline (El-Mashaleh, Minchin \& O’Brien, 2007) & $*$ & $*$ & & & & $*$ & $*$ & & * & & & & \\
\hline (Halman \& Voordijk, 2012) & & & & & $*$ & $*$ & & & & * & & $*$ & \\
\hline (Haponava \& Al-Jibouri, 2009) & & & & & & & & & & & & $*$ & \\
\hline (Horta, Camanho \& Da Costa, 2010) & & & & & $*$ & $*$ & $*$ & & & & & * & * \\
\hline (Kagioglou et al., 2001) & $*$ & $*$ & $*$ & & & $*$ & & $*$ & $*$ & & & * & \\
\hline (Latorre, Roberts \& Riley, 2010; Roberts \& Latorre, 2009) & $*$ & $*$ & $*$ & & $*$ & & * & $*$ & * & & & & \\
\hline (Luu, Kim, Cao \& Park, 2008) & $*$ & $*$ & * & $*$ & $*$ & $*$ & * & * & * & & & * & \\
\hline (Nasir et al., 2012) & $*$ & * & $*$ & & $*$ & & * & & & & & * & \\
\hline (Nudurupati, Arshad \& Turner, 2007) & $*$ & $*$ & $*$ & & $*$ & $*$ & $*$ & $*$ & * & & & * & \\
\hline (Pillai et al., 2002) & & $*$ & & & & $*$ & & * & * & & & $*$ & \\
\hline (Radujković, Vukomanović \& Dunović, 2010) & $*$ & $*$ & * & $*$ & $*$ & & * & & * & & & & \\
\hline (Ramirez et al., 2004) & & & & & & & & & & & & $*$ & \\
\hline (Rankin, Fayek, Meade, Haas \& Manseau, 2008) & $*$ & $*$ & $*$ & & & & * & & * & $*$ & & & \\
\hline (Ren, Anumba \& Yang, 2013) & & & & & & & & * & * & * & * & * & \\
\hline (Shaikh \& Darade, 2016) & $*$ & * & * & & & & & & & & & & \\
\hline (Skibniewski \& Ghosh, 2009) & $*$ & $*$ & $*$ & & $*$ & & $*$ & & $*$ & & & & \\
\hline (Toor \& Ogunlana, 2010) & $*$ & $*$ & * & & $*$ & $*$ & & $*$ & & & * & $*$ & \\
\hline (Wegelius-Lehtonen, 2001) & & $*$ & & & & $*$ & & & & & & & \\
\hline (Wong, 2004) & & & & & & & * & & & & & * & * \\
\hline (Yeung, Chan, Chan, Chiang \& Yang, 2013) & $*$ & $*$ & $*$ & & $*$ & $*$ & $*$ & $*$ & * & * & * & & * \\
\hline (Yu et al., 2007) & & $*$ & $*$ & & $*$ & $*$ & & * & $*$ & $*$ & & * & \\
\hline
\end{tabular}


To identify the existing indicators in the literature, a review was conducted using search strategies combining the following keywords: "performance", "benchmarking", "key performance indicators", "KPI", "construction industry", "building", and "housing". This search was focused on the Scopus database between 1996 and 2013. Neither congress publications, nor words other than those established in the predefined criteria were considered.

Table 1 shows the key performance indicators. This table comprises 35 publications ( 31 articles and 4 reports). A total of 108 indicators were classified into 13 categories; Table 1 details the categories, although specific indicators are not included in this article for space reasons. Grouping indicators (categories) corresponds to that used by the DETR (2000); as soon as additional indicators were detected, they were added to the list. The 108 performance indicators are integrated into a theoretical model applicable to housing developer-construction companies (see Figure 1). This model integrates two dimensions:

a) The life cycle of the project adapted from the proposal of Winch (2010), which considers four strategic phases: design, procurement, construction, and commissioning.

b) Strategic planning of the company in cascade considering three levels (Bassioni et al., 2005): strategic (senior management), tactical (middle management), and operational (production). This planning can also be approached from four different perspectives of the balanced scorecard (Kaplan \& Norton, 1996): financial, internal, customer, and innovation. The first two correspond to the strategic level, while the other two coincide with the tactical and operational levels, respectively.

The theoretical model proposes a set of performance measures for each level aligned to a strategic vision of the company throughout the infrastructure life cycle. At the operational level (bottom), production is monitored and decisions are made enabling the outcomes to accomplish the planned target. At the tactical level, the middle management performs benchmarking and rethinks strategies. Finally, the upper management is able to achieve the company's goals; generally, the board of directors only needs a summarized perspective of performance indicators. However, the tactic and operational levels need a set of performance indicators that map how the management and production efforts are aligned to the strategic plan. Furthermore, traceability enables the measurement of key performance indicators throughout the infrastructure life cycle that accomplish the planned objectives, guaranteeing a successful project.

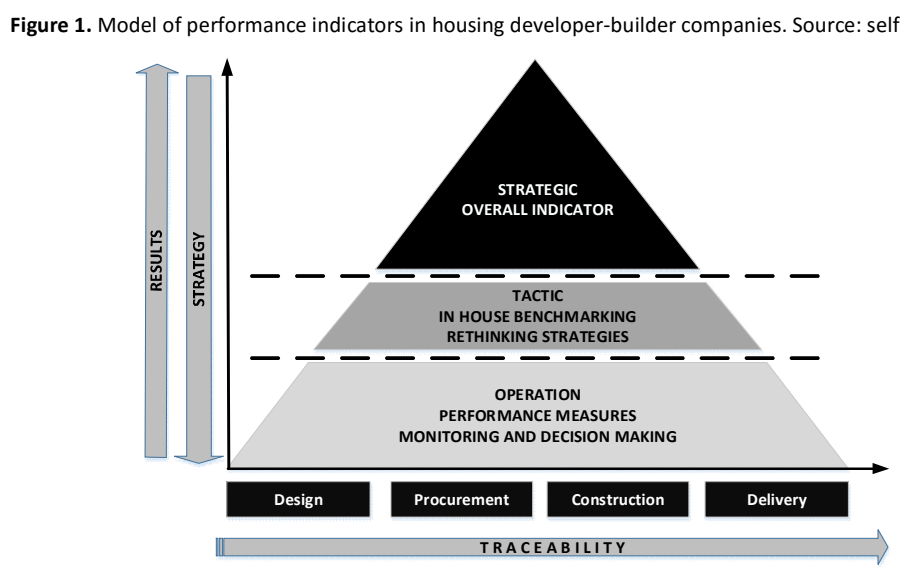

Validation of indicators: Delphi method

The Delphi method is widely used and accepted to achieve convergence of views through the use of experts (Alshubbak, Pellicer, Catalá, \& Teixeira, 2015; Hsu \& Sandford, 2007). The Delphi technique is designed as a group communication process whose main objective is to discuss and evaluate a specific topic in order to set goals or predict the occurrence of future events; it approaches research in a systematic and interactive way, giving rise to a panel of independent experts to assess a specific topic (Cortes, Pellicer, \& Catala, 2011; Hallowell \& Gambatese, 2010). This research method, it differs from traditional surveys, in that respondents are a small number of experts contrasted in certain predefined skills (Cortes et al., 2011). The consensus is achieved through an anonymous and controlled feedback provided by a facilitator for several rounds (Alshubbak et al., 2015; Hallowell \& Gambatese, 2010). 
The Delphi method has been applied in various fields such as program planning, needs assessment, policy determination and resource utilization (Hsu \& Sandford, 2007); it is particularly useful in contemporary research when: the target data are unattainable, there is a lack of empirical evidence, experimental research is unrealistic or unethical, or the diversity of the participants should be preserved to ensure the validity of results.

The application of the Delphi method in this research is intended to sort, evaluate, and synthesize a series of performance indicators according to the judgment of a selected panel of experts. Figure 2 describes the implementation process of the Delphi technique in this research (adapted from Hallowell \& Gambatese, 2010).

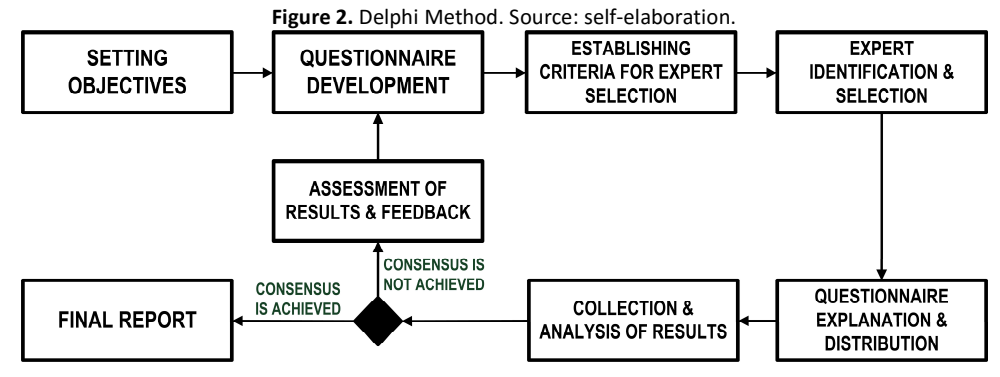

Each investigation has special characteristics that conditions the criteria used to determine the number and profile of the members of the panel of experts (Hsu \& Sandford, 2007); these authors recommend that the experts invited to participate know the problem to be analyzed and be willing to make positive contributions. Based on the above references and previous experience of the authors in similar studies (Alshubbak et al., 2015; Cortes et al., 2011), the need to determine a perfectly objective criterion led to the imposition that the panel members were university graduates, despite that other professional experts could also have contributed. In order to achieve a homogeneous distribution, the panel was composed of the following professional profiles (Cortes et al., 2011; Hallowell \& Gambatese, 2010):

a) Shareholders or owners of housing developer-builder companies.

b) Directors or senior management executives of housing developer-builder companies.

c) Consultants in the area of real estate developments.

d) Managers of housing construction projects.

e) University professors.

Similarly, it is recommended to consider the level of experience, according to the expert's professional profile (Alshubbak et al., 2015; Cortes et al., 2011). Hallowell \& Gambatesse (2010) consider that the most important factor to consider in forming the panel is the experience of its members. In this case, each member of the panel must meet one of the following requirements:

- At least 5 years as a manager or senior management administrative position in a residential housing developerbuilder company.

- At least 10 years as a shareholder, manager, consultant in real estate housing developments, or university professor on topics related to the construction industry.

\begin{tabular}{lccccc}
\multicolumn{7}{c}{ Table 2. Characteristics of the expert panel member profile. Source: self-elaboration. } \\
\hline Position & $\begin{array}{c}\text { Experience } \\
\text { (Years) }\end{array}$ & Profession & $\begin{array}{c}\text { Academic } \\
\text { Degree }\end{array}$ & $\begin{array}{c}\text { Years in the } \\
\text { company }\end{array}$ & Category \\
\hline Const. Control Manager & 5 & Accountant & B.Sc. & 4 & Manager \\
Construction CEO & 20 & Architect & B.Sc. & 20 & $\begin{array}{c}\text { Shareholder } \\
\text { Line Manager }\end{array}$ \\
Management and Finance & 7 & Civil Eng. & M.Sc. & 2 & Supervisor \\
Innovation and projects & 8 & Accountant & B.Sc. & 2 & Manager \\
Construction Manager & 13 & Architect & B.Sc. & 3 & Supervisor \\
Project Manager & 10 & Architect & M.Sc. & 6 & Manager \\
Construction CEO & 10 & Civil Eng. & M.Sc. & 10 & Manager \\
Professor & 7 & Civil Eng. & M.Sc. & 5 & Shareholder \\
Professor & 9 & Civil Eng. & Ph.D. & 5 & Consultant \\
Professor & 11 & Civil Eng. & M.Sc. & 9 & Academic \\
\hline
\end{tabular}


Table 3. Performance indicators selected by the panel of experts (self-elaboration).

\begin{tabular}{|c|c|c|}
\hline Category & Indicator & Mean \\
\hline \multicolumn{3}{|c|}{1 unimportant___ -5 highly important } \\
\hline \multirow[t]{2}{*}{ Time } & Schedule Performance & 4.5 \\
\hline & Time Predictability - Design - Construction & 4.6 \\
\hline \multirow[t]{3}{*}{ Cost } & Construction Cost & 4.8 \\
\hline & Cost Predictability - Design - Construction & 4.8 \\
\hline & Percentage Net Variation over Final Cost & 4.3 \\
\hline \multirow[t]{3}{*}{ Quality } & Defects & 4.8 \\
\hline & Quality Issues at Available for Use & 4.9 \\
\hline & Product Defect Number / Customer Complaints & 4.9 \\
\hline Changes & Change Orders (Project Manager) & 2.2 \\
\hline \multirow[t]{6}{*}{ Business } & Profitability (Company) & 4.9 \\
\hline & Profitability (Project) & 4.6 \\
\hline & Productivity (Company) & 4.5 \\
\hline & Productivity (Project) & 4.6 \\
\hline & Return of Capital Employed (Company) & 4.5 \\
\hline & Profit Predictability (Project) & 4.8 \\
\hline \multirow[t]{6}{*}{ Financial } & Financial Perspective & 4.5 \\
\hline & Cash Flow & 4.3 \\
\hline & Income & 4.9 \\
\hline & Return on Sales & 5.0 \\
\hline & Profit & 4.9 \\
\hline & Sales Growth & 4.6 \\
\hline \multirow[t]{4}{*}{ Safety and Environment } & Reportable Accidents (inc. Fatalities) & 4.9 \\
\hline & Accident Rate & 4.8 \\
\hline & Contractor's Performance Health and Safety & 4.6 \\
\hline & Environmental Impact / Sustainability & 4.5 \\
\hline Teamwork & Construction Team Satisfaction & 2.2 \\
\hline \multirow[t]{2}{*}{ Customer Satisfaction } & End Customer Satisfaction & 5.0 \\
\hline & Performance Measurement & 4.5 \\
\hline Innovation & Innovation & 2.0 \\
\hline \multirow[t]{3}{*}{ Efficiency } & Planning Efficiency & 4.9 \\
\hline & Efficiency of Direct Labor & 4.9 \\
\hline & Communications Efficiency & 4.6 \\
\hline \multirow[t]{2}{*}{ Contractor } & Contractor's Satisfaction & 4.8 \\
\hline & Leadership & 4.6 \\
\hline \multirow[t]{3}{*}{ Project Management } & Top Management Commitment & 4.9 \\
\hline & Time and Cost Management & 4.8 \\
\hline & Quality Management & 4.9 \\
\hline
\end{tabular}

Some authors (Cortes et al., 2011; Hallowell \& Gambatese, 2010) argue that, according to the most recent applications related to construction management, the average number of experts should be 16 , with a minimum of 10 . That is why, in terms of the number of panelists, 20 experts were invited to participate, equally divided among the four groups indicated above.

The minimum number of rounds so that consensus can be achieved is two. The questionnaire was sent in paper format, E-mail or personal interview (depending on the preference of the expert). In the application of the Delphi technique, it is important to have feedback between each round in order to achieve consensus among the anonymous panel members; without this iteration, the study may be invalid (Hallowell \& Gambatese, 2010).

In the present investigation, finally nine of the 20 participants did not accept the invitation, so definitely the final panel was composed of 11 members. Table 2 describes the characteristics of the experts who participated in the study. In Table 2 it can be considered that the three levels are represented (operational, tactical, and strategic), as managers and directors with academic training in construction (civil and architectural engineers) have passed through the lower levels as part of the development of their professional career. 
After conducting two rounds, a consensus among members of the panel of experts was reached: they chose 37 out of the 108 identified indicators. Table 3 shows the indicators that the panel of experts considered important for measuring performance in housing developer-builder companies, considering the same categories as in Table 1. Furthermore, Table 3 lists the indicators corresponding to each of the 13 perspectives selected based on their strategic importance (column 1) and their ease of implementation (column 2). These results are reflected based on the average value, taking into account the Likert scale: 1 (unimportant) to 5 (highly important from a strategic point of view and ease of implementation).

Most of the indicators selected by the panel of experts are not time-sensitive (they are lagging indicators) but they are sensitive to knowledge. The internal financial and business perspectives are composed mainly of such indicators. The time-sensitive indicators integrated into this model are the construction cost, revenue, sales, and profitability.

The indicators integrated into the model were those that met the average value of the mean of both, ease of implementation and strategic importance, and it was equal to or greater than 4.5. However, to maintain the representativeness of all of the considered categories, in those cases where no indicator of any category obtained an average greater than 4.5, the indicator that obtained the highest average for that category remained.

\section{Integration of the theoretical model}

As a result of the above, a theoretical model of performance measurement based on the same 37 indicators applicable to housing developer-builder companies is proposed; this model is shown in Figure 3 . This theoretical model reflects the experience of the analyzed previous studies. On the one hand, it includes the project life cycle considering the design, procurement, construction, and commissioning. On the other hand, it includes the company planning considering the integration in upstream and downstream cascade of both decision making and flow of information and achievement of objectives; lagging and leading indicators are integrated into the model. To maintain flexibility and adaptability of the model, it is proposed to incorporate the taxonomy proposed by Skibniewski \& Ghosh (2009) which defines performance indicators as time-sensitive and knowledge-sensitive. The 37 selected indicators are located on the model levels according to the level proposal from Wegelious-Lethonen (2001).

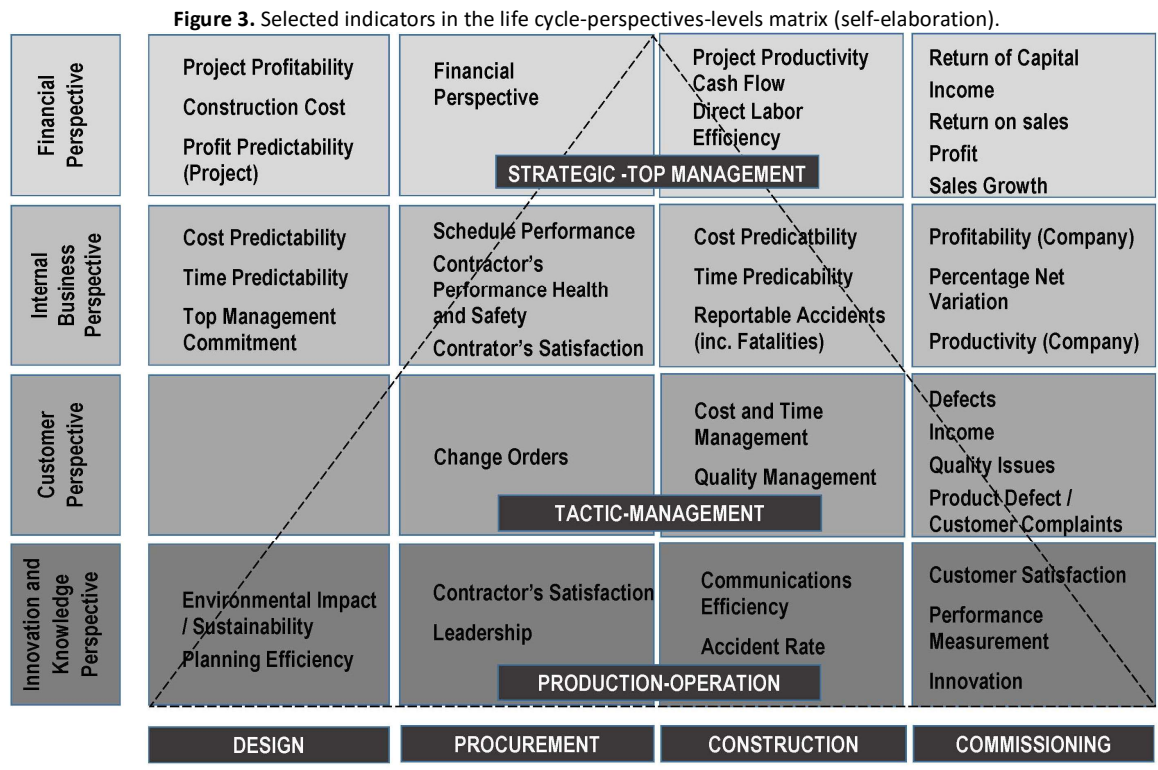

To complement the integration of the model, based on the Balanced Score Card (Kaplan \& Norton, 1996), the 37 indicators resulting from the Delphi study are located. Figure 3 shows the model that integrates the formulated $4 \times 4$ array. The matrix is formed in the horizontal dimension by the four stages of the project life cycle and in the vertical dimension by the four perspectives that make up the control frame: innovation and learning, customer, business, and finance. This integration allows the classification of indicators according to how they can act at different levels of the organization representing the pyramid: the financial perspective (top part: top management and strategic level), business and client perspectives (middle part: middle management and tactical level) and innovation and learning 
perspective (bottom part: production and operational level). In the proposal made in the model, each of the indicators should occupy a quadrant of the $4 \times 4$ matrix.

Discussion and Conclusions

Performance measurement in the construction industry has been conducted under theoretical models or measurement systems mainly based on lagging indicators (Haponava \& Al-Jibouri, 2012) and mainly at higher organizational levels, and not at the level of processes; an example of this is housing construction that is a set of repetitive processes enabling continuous improvement. According to Bassioni et al. (2005), there is still the need to describe and develop measures and guidelines for the implementation of performance measurement systems. Performance measurement leads to the development of tools to ensure the performance by defining key indicators involving the definition of best practices and the comparison among them under the concept of "benchmarking".

The current performance measurement systems should be flexible and dynamic and incorporate the necessary measurement indicators to keep the information provided to the directors updated, regarding company performance, process and project measurements. If a performance measurement system is not used for decision making in management, either due to their complexity or excessive content of indicators, it can be discarded. The model proposed in this research integrates, the strategy, which forms an important part of performance measurement (Bassioni et al., 2005), and the four basic perspectives of the Balanced Score Card: innovation and learning, customer, business, and finance. It also incorporates a number of indicators in these four perspectives: the model distributes them in the four phases of the project life cycle and the three levels of the organization (strategic, tactical and operational). The different levels of the organization need different indicators (Wegelius-Lehtonen, 2001). The approach given to these measurements constitutes the second dimension of the proposed indicator framework for housing developer-builder companies. The first and most important dimension are the indicators that unfold between the phases of the life cycle and the perspectives of the Balanced Score Card.

It is important to point out that while the integrated systems of performance indicators proposed by various authors (Bassioni, Price \& Hassan, 2004; Beatham et al., 2004; Costa et al., 2006; Formoso \& Lantelme, 2000; among others) cover different objectives, there is no evidence of an integrated performance measurement model that includes the concepts that this model proposes: strategy display by organizational level, life cycle, perspectives, indicators and their sensitivity (at the time they are obtained). The proposed model, in any case, shall be subjected to subsequent validation through case studies to verify its applicability in the developer-builder companies working in the residential housing sector.

The lack of information about best practices among businesses and specifically these used as a competitive and market advantage prevents, somehow, that models such as the proposed in this research cannot be efficiently back fed, at least in Mexico. In order to have quality information, the researcher has the arduous task of proving that by permeating the best practices across the entire industry not only customers but also employers and employees can benefit from the use and application of such models. As a future line of research, it remains to complement a third round where the definition of each indicator and how to get the information generated in companies is provided. Moreover, the model must also be implemented using case studies in order to assess its contribution to the performance improvement of Mexican housing developer-builder companies.

\section{Acknowledgments}

The authors thank CONACYT and the Institute for Innovation and Technology Transfer "I2T2" of the state of Nuevo Leon (Mexico) for the support provided to the first author of this article which enabled him to start his Ph.D. studies at the Universitat Politècnica de València (Spain).

References

Alarcón, L. F., \& Ashley, D. B. (1996). Modeling Project Performance for Decision Making. Journal of Construction Engineering and Management, 122(3), 265-273. https://doi.org/10.1061/(ASCE)0733-9364(1996)122:3(265)

Ali, H. A. E. M., Al-Sulaihi, I. a., \& Al-Gahtani, K. S. (2013). Indicators for measuring performance of building construction companies in Kingdom of Saudi Arabia. Journal of King Saud University - Engineering Sciences, 25(2), 125-134. https://doi.org/10.1016/j.jksues.2012.03.002 
Alshubbak, A., Pellicer, E., Catalá, J., \& Teixeira, J. M. C. (2015). A model for identifying owner's needs in the building life cycle. Journal of Civil Engineering and Management, 21(8), 1046-1060. https://doi.org/10.3846/13923730.2015.1027257

Balatbat, M. C. A., Lin, C., \& Carmichael, D. G. (2010). Comparative performance of publicly listed construction companies: Australian evidence. Construction Management and Economics, 28(9), 919-932. https://doi.org/10.1080/01446193.2010.501805

Bassioni, H. A., Price, A. D. F., \& Hassan, T. M. (2004). Performance Measurement in Construction. Journal of Management in Engineering, 20(2), 4250. https://doi.org/10.1061/(ASCE)0742-597X(2004)20:2(42)

Bassioni, H. A., Price, A. D. F., \& Hassan, T. M. (2005). Building a conceptual framework for measuring business performance in construction: an empirical evaluation. Construction Management and Economics, 23(5), 495-507. https://doi.org/10.1080/0144619042000301401\}

Beatham, S., Anumba, C., Thorpe, T., \& Hedges, I. (2004). KPIs: a critical appraisal of their use in construction. Benchmarking: An International Journal, 11(1), 93-117. https://doi.org/10.1108/14635770410520320

Bititci, U. S., Carrie, A. S., \& McDevitt, L. (1997). Integrated performance measurement systems: a development guide. International Journal of Operations \& Production Management, 17(5), 522-534. https://doi.org/10.1108/01443579710167230

Butcher, D. C. A., \& Sheehan, M. J. (2010). Excellent contractor performance in the UK construction industry. Engineering, Construction and Architectural Management, 17(1), 35-45. https://doi.org/10.1108/09699981011011302

Chan, A. P. C., \& Chan, A. P. L. (2004). Key performance indicators for measuring construction success. Benchmarking: An International Journal, 11(2), 203-221. https://doi.org/10.1108/14635770410532624

Chan, T. K. (2009). Measuring performance of the Malaysian construction industry. Construction Management and Economics, 27(12), 1231-1244. https://doi.org/10.1080/01446190903233137

Cheah, C. Y. J., Garvin, M. J., \& Miller, J. B. (2004). Empirical Study of Strategic Performance of Global Construction Firms. Journal of Construction Engineering and Management, 130(6), 808-817. https://doi.org/10.1061/(ASCE)0733-9364(2004)130:6(808)

Cheung, S. O., Suen, H. C. H., \& Cheung, K. K. W. (2004). PPMS: a Web-based construction Project Performance Monitoring System. Automation in Construction, 13(3), 361-376. https://doi.org/10.1016/j.autcon.2003.12.001

CII. (2011). Benchmarking and Metrics Data Report 2011. Austin, Texas.

Construction Industry Institute. (2011). Benchmarking and Metrics Data Report 2011. Austin, Texas.: Construction Industry Institute.

Cortés, J. M., Pellicer, E., \& Catalá, J. (2012). Integration of Occupational Risk Prevention Courses in Engineering Degrees: Delphi Study. Journal of Professional Issues in Engineering Education and Practice, 138(1), 31-36. https://doi.org/10.1061/(ASCE)EI.1943-5541.0000076

Costa, D. B., Formoso, C. T., Kagioglou, M., Alarcón, L. F., \& Caldas, C. H. (2006). Benchmarking Initiatives in the Construction Industry: Lessons Learned and Improvement Opportunities. Journal of Management in Engineering, 22(4), 158-167. https://doi.org/10.1061/(ASCE)0742597X(2006)22:4(158)

Costa, D. B., Formoso, C. T., \& Lantelme, E. M. V. (2002). Critérios para desenvolvimento de sistemas de indicadores de desempenho vinculados aos objetivos estratégicos de empresas da construção civil. In XXII Congresso Nacional de Engenharia de Produção (1-8). Rio de Janeiro, Brasil: ABEPRO.

Costa, D. B., Formoso, C. T., \& Lantelme, E. M. V. (2000). critérios para desenvolvimento de sistemas de indicadores de desempenho vinculados aos objetivos estratégicos de empresas da construção civil. In XXII Encontro Nacional de Engenharia de Produção (22). Rio de Janeiro, Brasil: ABEPRO.

Cox, R. F., Issa, R. R. A., \& Ahrens, D. (2003). Management's Perception of Key Performance Indicators for Construction. Journal of Construction Engineering and Management, 129(2), 142-151. https://doi.org/10.1061/(ASCE)0733-9364(2003)129:2(142)

Dawood, N. (2010). Development of 4D-based performance indicators in construction industry. Engineering, Construction and Architectural Management, 17(2), 210-230. https://doi.org/10.1108/09699981011024704

Dawood, N., \& Sikka, S. (2009). Development of 4D based performance indicators in construction industry. Engineering, Construction and Architectural Management, 16(5), 438-458. https://doi.org/10.1108/09699980910988357

Department of the Environment Transport and the Regions. (2000). KPI Report for the Minister for Construction, KPI Working Group. London, UK: Department of the Environment Transport and the Regions.

Dong Wook, L., \& Nam-Sik, K. (2015). Interaction Analysis between Construction Business Indicators and Business Performance Indicators of Specialty Contractors Depending on Operation Types. Journal of the Korean Society of Civil Engineers, 35(1), 193. https://doi.org/10.12652/Ksce.2015.35.1.0193

Eagan, J. (1998). Rethinking Construction. London, UK: Department of the Environment, Transport and the Regions.

El-Mashaleh, M. S., Edward Minchin, R., \& O’Brien, W. J. (2007). Management of Construction Firm Performance Using Benchmarking. Journal of Management in Engineering, 23(1), 10-17. https://doi.org/10.1061/(ASCE)0742-597X(2007)23:1(10)

Excellence, C. (2011). UK Construction KPIs 2011. London, UK: Department for Bussines Innovation and Skills.

Formoso, C. T., \& Lantelme, E. M. (2000). A performance measurement system for construction companies in Brazil. International Project Management Journal, 6(3), 54-60.

Ghalayini, A. M., \& Noble, J. S. (1996). The changing basis of performance measurement. International Journal of Operations \& Production Management, 16(8), 63-80. https://doi.org/10.1108/01443579610125787 
Hallowell, M. R., \& Gambatese, J. A. (2010). Qualitative Research: Application of the Delphi Method to CEM Research. Journal of Construction Engineering and Management, 136(1), 99-107. https://doi.org/10.1061/(ASCE)C0.1943-7862.0000137

Halman, J. I. M., \& Voordijk, J. T. (2012). Balanced Framework for Measuring Performance of Supply Chains in House Building. Journal of Construction Engineering and Management, 138(12), 1444-1450. https://doi.org/10.1061/(ASCE)CO.1943-7862.0000553

Haponava, T., \& Al-Jibouri, S. (2012). Proposed system for measuring project performance using process-based key performance ndicators. Journal of Management in Engineering, 28(2), 140-149. https://doi.org/10.1061/(ASCE)ME.1943-5479.0000078

Haponava, T., \& Al-Jibouri, S. (2009). Identifying key performance indicators for use in control of pre-project stage process in construction. International Journal of Productivity and Performance Management, 58(2), 160-173. https://doi.org/10.1108/17410400910928743

Haponava, T., \& Al-Jibouri, S. (2010). Influence of process performance during the construction stage on achieving end-project goals. Construction Management and Economics, 28(8), 853-869. https://doi.org/10.1080/01446193.2010.487535

Horta, I. M., Camanho, A. S., \& Da Costa, J. M. (2010). Performance Assessment of Construction Companies Integrating Key Performance Indicators and Data Envelopment Analysis. Journal of Construction Engineering and Management, 136(5), 581-594. https://doi.org/10.1061/(ASCE)CO.1943-7862.0000145

Hsu, C.-C., \& Sandford, B. A. (2007). The Delphi technique: Making sense of consensus. Practical Assessment, Research \& Evaluation, 12(10).

Hwang, B.-G., \& Zhao, X. (2015). Review of global performance measurement and benchmarking initiatives. International Journal of Construction Management, 15(4), 265-275. https://doi.org/10.1080/15623599.2015.1083410

Kagioglou, M., Cooper, R., \& Aouad, G. (2001). Performance management in construction: a conceptual framework. Construction Management and Economics, 19(1), 85-95. https://doi.org/10.1080/01446190010003425

Kaplan, R. S., \& Norton, D. P. (1996). The Balanced Scorecard: Translating Strategy into Action (First). Boston, USA: HBS Press.

Kaplan, R. S., \& Norton, D. P. (2003). Balanced Scorecard. Boston, USA: HBS Press.

Kärnä, S., \& Junnonen, J.-M. (2016). Benchmarking construction industry, company and project performance by participants' evaluation Benchmarking: An International Journal, 23(7), 2092-2108. https://doi.org/10.1108/BIJ-05-2015-0050

Latham, M. (1994). Constructing the Team (First). London, UK: HM Stationery Office.

Latorre, V., Roberts, M., \& Riley, M. J. (2010). Development of a Systems Dynamics Framework for KPls to Assist Project Managers' Decision Making Processes. Revista de La Construcción, 9(1), 39-49. https://doi.org/10.4067/S0718-915X2010000100005

Lim, W., Jung, J., \& Lee, H. (2015). Extraction of the key performance indicators of construction management using balanced score card. Korean Journal of Construction Engineering and Management, 16(6), 22-30.

Luu, T.-V., Kim, S.-Y., Cao, H.-L., \& Park, Y.-M. (2008). Performance measurement of construction firms in developing countries. Construction Management and Economics, 26(4), 373-386. https://doi.org/10.1080/01446190801918706

Nasir, H., Haas, C. T., Rankin, J. H., Fayek, A. R., Forgues, D., \& Ruwanpura, J. (2012). Development and implementation of a benchmarking and metrics program for construction performance and productivity improvement 11 This paper is one of a selection of papers in this Special Issue on Construction Engineering and Management. Canadian Journal of Civil Engineering, 39(9), 957-967. https://doi.org/10.1139/I2012-030

Neely, A., Bourne, M., Mills, J., Platts, K., \& Richards, H. (2002). Strategy and Performance: Getting the Measure of Your Business (First, Vol. 2). Cambridge, UK: Cambridge University Press.

Neyestani, B., \& Juanzon, J. B. P. (2016). Developing an Appropriate Performance Measurement Framework for Total Quality Management (TQM) in Construction and Other Industries. IRA-International Journal of Technology \& Engineering (ISSN 2455-4480), 5(2), 32. https://doi.org/10.21013/jte.v5.n2.p2

Nudurupati, S., Arshad, T., \& Turner, T. (2007). Performance measurement in the construction industry: An action case investigating manufacturing methodologies. Computers in Industry, 58(7), 667-676. https://doi.org/10.1016/j.compind.2007.05.005

Nudurupati, S. S., Bititci, U. S., Kumar, V., \& Chan, F. T. S. (2011). State of the art literature review on performance measurement. Computers \& Industrial Engineering, 60(2), 279-290. https://doi.org/10.1016/j.cie.2010.11.010

O’Brien, W. J., Formoso, C. T., Vrijhoef, R., \& London, K. A. (2009). Construction Supply Chain Management Handbook (First). Boca Raton, USA: CRC Press.

Pellicer, E., Yepes, V., Teixeira, J. C., Moura, H. P., \& Catala, J. (2014). Construction Management (First). Oxford, UK: Wiley-Blackwell.

Pillai, A. S., Joshi, A., \& Rao, K. S. (2002). Performance measurement of R\&D projects in a multi-project, concurrent engineering environment. International Journal of Project Management, 20(2), 165-177. https://doi.org/10.1016/S0263-7863(00)00056-9

Project Management Institute. (2013). Guide to the Project Management Body of Knowledge (PMBOK $\left.{ }^{\circledR}\right)$ (Fifth Edit). Newtown Square, USA: Project Management Institute.

Radujković, M., Vukomanović, M., \& Dunović, I. B. (2010). Application of key performance indicators in South-Eastern European construction. Journal of Civil Engineering and Management, 16(4), 521-530. https://doi.org/10.3846/jcem.2010.58

Ramrez, R. R., Alarcón, L. F. C., \& Knights, P. (2004). Benchmarking System for Evaluating Management Practices in the Construction Industry. Journal of Management in Engineering, 20(3), 110-117. https://doi.org/10.1061/(ASCE)0742-597X(2004)20:3(110)

Rankin, J., Fayek, A. R., Meade, G., Haas, C., \& Manseau, A. (2008). Initial metrics and pilot program results for measuring the performance of the Canadian construction industry. Canadian Journal of Civil Engineering, 35(9), 894-907. https://doi.org/10.1139/L08-018 
Ren, Z., Anumba, C. J., \& Yang, F. (2013). Development of CDPM matrix for the measurement of collaborative design performance in construction. Automation in Construction, 32, 14-23. https://doi.org/10.1016/j.autcon.2012.11.019

Roberts, M., \& Latorre, V. (2009). Indicadores de desempeño en la industria de la construcción en el Reino Unido: Usando sistemas dinámicos para entender el incumplimiento de metas. Revista e La Construcción, 8(1), 69-82.

Rouse, P., Putterill, M., \& Ryan, D. (1997). Towards a General Managerial Framework for Performance Measurement: A Comprehensive Highway Maintenance Application. Journal of Productivity Analysis, 8(2), 127-149. https://doi.org/10.1023/A:1007743606303

Sarkar, D., Raghavendra, H. B., \& Ruparelia, M. (2015). Role of key performance indicators for evaluating the usage of BIM as tool for facility management of construction projects. Interational Journal of Civil and Structural Engineering, 5(4), 370-378. https://doi.org/10.6088/ijcser.2014050034

Shaikh, S. S., \& Darade, M. M. (2016). Assessment of key performance indicators in project quality plan for construction project. Global Research and Development Journal for Engineering, 1(12), 126-131.

Skibniewski, M. J., \& Ghosh, S. (2009). Determination of Key Performance Indicators with Enterprise Resource Planning Systems in Engineering Construction Firms. Journal of Construction Engineering and Management, 135(10), 965-978. https://doi.org/10.1061/(ASCE)07339364(2009)135:10(965)

Toor, S.-R., \& Ogunlana, S. O. (2010). Beyond the "iron triangle": Stakeholder perception of key performance indicators (KPIs) for large-scale public sector development projects. International Journal of Project Management, 28(3), 228-236. https://doi.org/10.1016/j.ijproman.2009.05.005

Towill, D. R. (2001). The idea of building business processes: the responsive housebuilder. Construction Management and Economics, 19(3), 285-293. https://doi.org/10.1080/01446190010020408

Wegelius-Lehtonen, T. (2001). Performance measurement in construction logistics. International Journal of Production Economics, 69(1), $107-116$. https://doi.org/10.1016/S0925-5273(00)00034-7

Winch, G. M. (2009). Managing Construction Projects (Second Edition). London, UK: John Wiley \& Sons.

Wong, C. H. (2004). Contractor Performance Prediction Model for the United Kingdom Construction Contractor: Study of Logistic Regression Approach Journal of Construction Engineering and Management, 130(5), 691-698. https://doi.org/10.1061/(ASCE)0733-9364(2004)130:5(691)

Xiao, H., \& Proverbs, D. (2002). The performance of contractors in Japan, the UK and the USA: a comparative evaluation of construction cost. Construction Management and Economics, 20(5), 425-435. https://doi.org/10.1080/01446190210145859

Yeung, J. F. Y., Chan, A. P. C., Chan, D. W. M., Chiang, Y. H., \& Yang, H. (2013). Developing a Benchmarking Model for Construction Projects in Hong Kong. Journal of Construction Engineering and Management, 139(6), 705-716. https://doi.org/10.1061/(ASCE)CO.1943-7862.0000622

Yu, I., Kim, K., Jung, Y., \& Chin, S. (2007). Comparable Performance Measurement System for Construction Companies. Journal of Management in Engineering, 23(3), 131-139. https://doi.org/10.1061/(ASCE)0742-597X(2007)23:3(131) 